\title{
Social and Environmental Impacts of Artisanal and Small-scale Gold Mining: The Case of Chimanimani National Park
}

\author{
Chapanga Isaias ${ }^{1}$, Luís Cristóvão ${ }^{1}$, Gonzaga Chilole ${ }^{1}$, Eduardo Pinto Mulima² \\ 1. Faculty of Environmental Engineering and Natural Resources, Zambeze University, Mozambique \\ 2. Agricultural Research Institute of Mozambique, Centre Zonal Centre, Mozambique
}

\begin{abstract}
In Mozambique, artisanal and small-scale mining provides a livelihood for many people and is an important source of economic development for many rural communities. The number of people involved in those activities is likely growing due to population growth, poverty, high price of mineral and climate change. However, there are many social and environmental problems directly associated with gold mining that overshadowed these economic gains. In this sense, the study aimed to analyze the social and environmental impacts of artisanal mining in the Chimanimani National Park and the relevant legislation. Methodologically, it was used a literature review and field research, with a sample of 28 interviewees. The collected data were processed on IBM SPSS statistical package, version 20.0 and analyzed at a level of significance of 5\%. The results showed that the development of artisanal mining activities in the Chimanimani National Park, despite providing employment and income, has created problems of soil erosion, clearance of vegetation and water pollution, in addition to the degeneration of areas agricultural, which threatens the local socio-environmental well-being.
\end{abstract}

Keywords: artisanal gold mining, climate change, Chimanimani National Park, environment, pollution

DOI: $10.7176 / \mathrm{JRDM} / 79-05$

Publication date:October $31^{\text {st }} 2021$

\section{INTRODUCTION}

Mozambique, a country long scarred by poverty, is endowed with a variety of natural resources. However, this biodiversity is already under threat from a number of natural as well as human-induced pressures. Approximately $80 \%$ of the population is rural and have long coped with the risk by generating their incomes from several natural resources. As populations grow and the consumption increases, these drive to a rapid extract more economically valuable resources as minerals, timber or food. Despite the evidence of multiple income-earning activities from natural resources, much development policy continues to view rural families as solely agricultural, being this activity often affected by climate change and consequently promotes a farm agenda.

Biodiversity supports human welfare and livelihoods. At least 13 of the 17 UN SDGs depend on biodiversity, including ecosystem diversity. Thus, the Government of Mozambique in its Strategic Plan (2019-2024) highlighted: (i) a moral imperative to conserve for future generations the rich and dynamic biodiversity; and (ii) a moral imperative to lift the mass of people in low-income out of abject poverty. For Mozambique, finding a balance that ensures economic growth in terms of GDP while maintaining functional natural ecosystems and maintaining social equity with a fair distribution of income, constitutes the main challenge to this day. The economic considerations often override the environmental and social considerations. Thus, achieving these SDGs will require a nexus approach.

The National Park of Chimanimani (NPC) is recognized to be one of the world's biodiversity hotspots: vegetation ranges from lowland rainforest to afro-alpine meadows counting more than 150 endemic or endangered plant species and several endemic amphibian, reptile and bird species (Dondeyne et al. 2009 and Ganje et al. 2021)

The creation and management of conservation areas are among the main instruments of environmental policy for the preservation of biological diversity. Hence, changing the reserve category to the NPC was an excellent strategy for protecting biodiversity, but the park's conservation effectiveness is also related to the monitoring of surrounding activities. However, despite being a fully protected area, certain factors fuel the continued increase in the number of people who practice agriculture and artisanal and small-scale mining (ASM). National legislation forbids any economic activity from taking place in NPC, including mining. Government authorities had declared that they would put an end to illegal mining in the park, but these efforts have proven totally ineffective due to the logistic difficulties.

Although the ASM sector has long been a mainstay of Mozambique's rural economy, it poses a growing threat to biodiversity and the integrity of protected areas. The activities in protected areas are frequently the precursor for even more destructive impacts, opening up areas to illicit exploitation. Due to its nature, data on the sector has rarely been structurally gathered and analyzed. The absence of such baseline information hinders informed decision making on the future development of the sector and the design of appropriate poverty reduction strategies. Without effective measures to conserve biodiversity and use its components in a sustainable manner, the 2030 Agenda for Sustainable Development will not be achievable. 
Most ASM work in the informal sector either illegally or in legal areas without licenses, permits or title to mining areas. The increasing price of precious minerals has launched rushes in the country. These rushes are attracting people to previously untouched places that are important conservation sites, including within protected areas. Thus, this work aims to analyze the socio-environmental impacts of ASM in the NPC, working conditions and relevant legislation on the subject.

\section{MATERIAL AND METHODS}

The present study was conducted in the Province of Manica, District of Sussundenga, Community of Tsetsera, in the National Park of Chimanimani (NPC). The data collection guide (Table 1) was composed of dependent and independent variables according to Lakatos and Marconi (2003). In NPC, the Community of Tsetsera has a total of 256 households (INE, 2017). For determination the sample size the method of Case (1990) was used, resulting in a sample of 26 households. To enrich the results, two more members were interviewed, first a member of the Tsetsera Association and then a PNC employee. Thus, the size of the sample resulted in 28 interviewees.

Table 1: Dependent and independent variables of the study

\begin{tabular}{|c|c|c|}
\hline $\begin{array}{c}\text { Dependent variables } \\
(\mathbf{Y})\end{array}$ & Independent variables $(\mathrm{X})$ & Methods \\
\hline \multirow{2}{*}{$\begin{array}{l}\text { Comply with mineral } \\
\text { legislation }\end{array}$} & Local communities, local authorities and associations & Semi structured interview \\
\hline & Mining license & $\begin{array}{l}\text { Literature review/ } \\
\text { Unsystematic observation }\end{array}$ \\
\hline $\begin{array}{l}\text { Analysis of socio- } \\
\text { environmental impacts } \\
\text { arising from artisanal } \\
\text { mining }\end{array}$ & $\begin{array}{l}\text { - Mining problems and conflicts; } \\
\text { - } \quad \text { Negative impacts of artisanal gold mining; } \\
\text { - Type of technology used for mining and } \\
\text { processing, form of organization of the mine; } \\
\text { Data on those participating in mining by age } \\
\text { group and gender. }\end{array}$ & Questionnaire \\
\hline
\end{tabular}

For data collection, the "Kobotoolbox" tool was used, which allows data collection in the field using smartphones or tablets, as well as with paper or computers (Schmied, 2018). The questionnaires were prepared in Excel XLS following a standardized "programming language". For data processing and analysis, responses were first selected and standardized, followed by coding and tabulation. Statistical analysis was performed using the IBM SPSS statistical package version 20, where analysis of variance (ANOVA) was performed and comparison of means using the Tukey test at 5\% confidence interval.

As for the characterization of the interviewees, there was $20 \%$ female and $80 \%$ male. Of this number, $20 \%$ corresponded to the age group between $18-35$ years old, $48 \%$ corresponded to the age group between $35-45$ years old, $28 \%$ between $45-65$ years old and $4 \%$ over the age of 65 years old.

\section{RESULTS AND DISCUSSION}

\subsection{Socio-environmental impacts of artisanal gold mining on the PNC in Tsetsera}

From the study sample, there is evidence that the socio-environmental impacts of artisanal mining in Tsetsera are of great magnitude, affecting both the community and the miners. Regarding the problems that affect miners, it was noted from interviews that the lack of adequate instruments $(45 \%)$, lack of training (43\%) and social conflicts $(12 \%)$ are the most frequent problems for miners. Also, it was observed the use of rudimentary instruments, such as shovels, hoes, pickaxes, wheelbarrows. A study by Deniasse (2019) indicates that the risks are associated with the lack of means of protection such as helmets and boots, causing injuries due to falling blocks on the miner. Villegas et al. (2012) states that ASM uses very simple and low-cost methods, uses mining technologies and also benefits from low cost, easy installation and mobility, and the activity generally takes place in small deposits, with a useful life not exceeding 5 years old and in regions with difficult access.

Next to agriculture, artisanal gold mining is the second largest sector in terms of employment in Manica Province. Rural people benefit not only from the direct employment but also from trading opportunities the mining engenders. Miners reported to gain around $2 \mathrm{~g}$ of gold per day, which represent an income much higher than agriculture could offer. Although social conflict presents $12 \%$ of the problems that affect miners, conflicts tend to increase due to the demographic increase of the population. There have been several problems resulting from conflicts, such as: robbery (35\%), marginality $(40 \%)$, adultery and others $(25 \%)$, reported the interviewees. Escalating violence could easily jeopardize the park's potential for tourism once visitors' safety cannot be guaranteed (Dondeyne et al. 2009). The lack of adequate instruments is directly linked to the environmental problems caused by mining activity, both miners and the community of Tsetsera point out that mining activity causes problems of soil erosion, water pollution to the environment and soil impoverishment, as well as illustrates Figure 1. Bitar (1997) indicates that mining causes a set of unwanted effects that can be called externalities, namely: environmental changes, land use conflicts, depreciation of surrounding properties, generation of degraded areas 
and disturbances to urban traffic. Also, mining substantially alters the physical environment, causing deforestation, erosion, contamination of water bodies, increased dispersion of heavy metals, changes in the landscape and soil, in addition to compromising the fauna and flora.

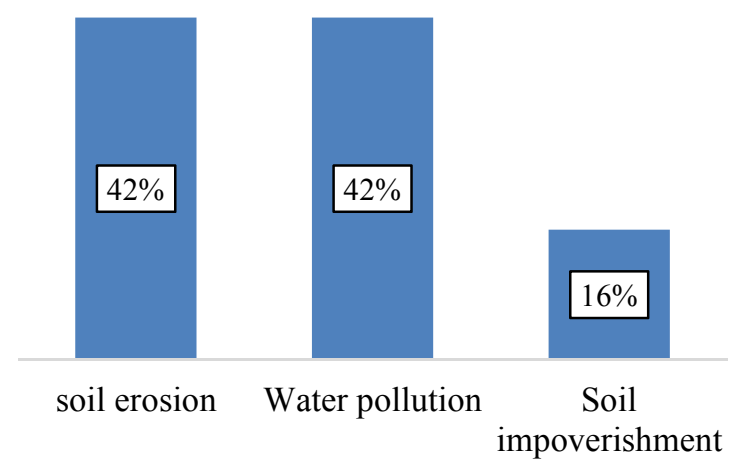

Figure 1: Environmental problems caused by mining activity

On the other hand, many interviewees reported that water turbidity $(38 \%)$ is the problem that is most felt in the community, followed by the injury and death of people and animals due to falls into abandoned wells (36\%) and the loss of soils and destruction of agriculture due to mining (26\%). The study by Deniasse (2019) indicates that deaths, mutilations and injuries in mines is considered to be the second biggest problem of mines. These problems have negative consequences in families, since, having lost or reduced the respective head of the family to physical disability, it makes it impossible to acquire what is necessary for their survival.

As mentioned before, water turbidity is one of the main problems resulting from artisanal gold mining for the Tsetsera community, this problem has as negative consequences/impacts the destruction of irrigation equipment due to the use of turbid water and disease transmission. Several studies report that these risks are due to the inhalation of mercury vapors, the consumption of inappropriate water, the absence of a sanitation system that can lead to the development of diarrheal diseases. Mercury, which is used to recover fine powder gold through an amalgamation process, is another environmental concern. The mercury vapors, mostly evaporated over an open fire, are very toxic and pose the highest risk to the operator (Dondeyne et al. 2009).

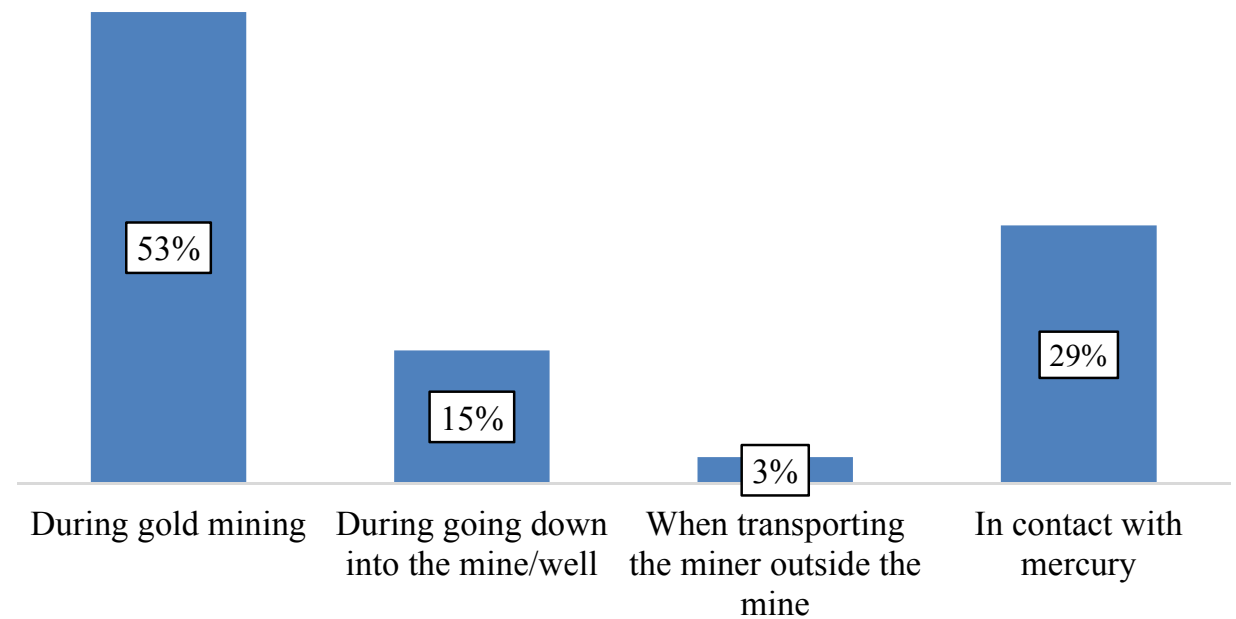

Figure 2: Work accidents during the gold mining and treatment process

In addition to the environmental problems caused by the mining activity and mining problems for the Tsetsera community, there are work accidents that occur during the gold mining and treatment process, the results obtained indicate that the majority of those interviewed stated that they have had work accidents during the extraction of gold and minority when transporting the ore outside the mine, as illustred in Figure 2. A study carried out by the Community Land Initiative (ITC, 2010), shows that in the practice of mining without following elementary safety methods, there have been several landslides due to the lack of stability of the slopes.

Figure 3 illustrates that all miners use mercury while working. They stated that they know how to handle it perfectly, and that most of them on average use between 10-20 grams. A study carried out by the United Nations 
Industrial Development Organization (UNIDO) in 2005 on the presence of mercury in miners in the Munhena Mine, whose results were fixed at $8.23 \mu \mathrm{g} / \mathrm{m} 3$, well above the levels acceptable by the World Health Organization (WHO).

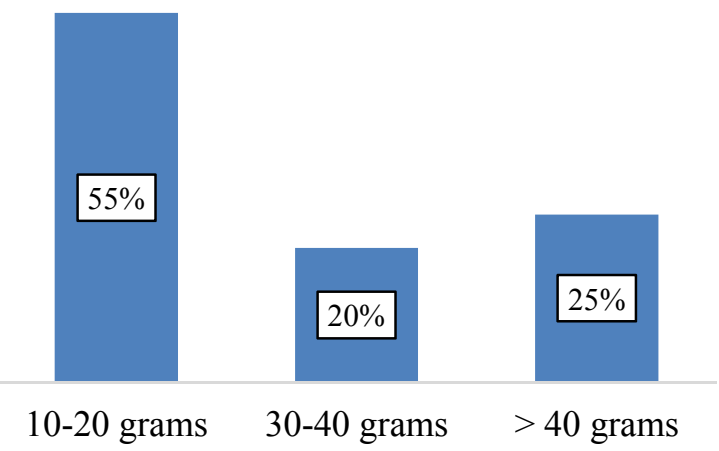

Figure 3: Amount of Mercury in miners

As for education and training on access to and rights over natural resources, most miners responded that there is a need for training, as $75 \%$ said they did not have access to training and $25 \%$ of the miners stated that they have some type of education and training. It was observed that there is still a continuous challenge for the development of capacity building and awareness activities, because artisanal miners are constantly changing with the arrival of new miners. ASM training in Mozambique are limited, with most training programs including those targeting government officials, delivered through externally funded projects. It is therefore critical to find a sustainable way to supply the needed skills to the growing Mozambican ASM sector in order to realize its full potential and transformation.

Considering the presence of children in mining (child labor or not), opinions are divided, a small portion $(30 \%)$ thinks that the presence of children is necessary in mining, while the majority (70\%) say no, it is not necessary, as the work carried out in the mines is very arduous and there is a greater probability of accidents at work, they stress that the place for small children is at school. As the ITC report (2010) indicates, the use of child labor is a fact that violates the rights of children and communities in general. communities and mining operators who look at the situation as a normal cultural learning process so that kids can safely face the future.

\subsection{Applicability of the Mining Law on socio-environmental impacts}

Government introduced several interventions and support structures to drive the development of the ASM sector, such as: law no. 20/2014 of 18 August: Mining Law, law 20/97 of 1 October: Environment Law, and decree no. 26/2004 of 20 August: environmental regulation for mining activities. Despite these policy and legislative interventions, ASM sector continues to experience challenges. The sector remains largely informal. The extent of the sector in terms of the players involved, number of people employed, its socio-economic impact, investments, and contribution to the Gross Domestic Product (GDP) and in the form of taxes is not properly documented.

From the study, it was observed that miners do not comply with mineral legislation, putting the economic issue ahead of the environmental one and compromising not only the conservation objectives of the protected areas, but also the essential products and services to life from natural ecosystems. Also, it was observed that members of NPC and association have knowledge about the instruments of environmental management, as set out in decree no. 26/2004, in article 7, but were unanimous in answering that they are unaware of the Environmental Management Plan.

Regarding to the exploration license "mining pass", most miners claim that they do not have any exploration license, even so, miners have access to land to carry out their activities, most miners are able to access land through of the local leadership (65\%), that is, local leaders are the facilitating agents in accessing land, on the other hand, the minority (15\%) seek local authorities (such as the head of the administrative post) and another part appeals to the competent authorities, as mentioned in the CIP monitoring report (2010), where it disputes the effectiveness of the mining pass and claims that the reality on the ground has shown that the "mining pass" is a failed instrument and that the legal and institutional framework of this sector is out of step with daily practice.

According to Decree $n^{\circ}$ 25/2011 of 15 November, which approves the Regulation on the Environmental Audit Process, the environmental audit can be public or private. Thus, in the mines of the Association of Tsetsera, the public audit process is mostly carried out by the PNC environmental education officer, but also, at the district level, it is carried out by the district services of planning and land use and infrastructure, as well as at the level of the administrative post.

Despite the Government's discourse, the policy and legal framework in place in Mozambique is evidently inadequate for improving artisanal miners' working conditions. Developing more authority to community leaders, 
in line with ongoing decentralization policy, could alleviate part of these deficiencies (Dondeyne et al. 2009).

\section{CONCLUSION}

Based on the results obtained in the community of Tsetsera - Chimanimani National Park, it was possible to conclude that:

1. Artisanal and small-scale mining is thought to be a particularly attractive livelihood option for people from both rural areas because it generates quick and high economic returns compared to traditional livelihoods, while requiring low specialized knowledge;

2. Most of the miners interviewed indicated they would be willing to leave the mining sector if they could find alternative sources of revenue;

3. Artisanal mining is carried out in a rudimentary and predatory way, requiring great physical effort on the part of miners, which encourages various processes of environmental degradation;

4. The assessment of impacts arising from the activity of artisanal mining pointed out: soil erosion, water pollution and soil impoverishment, having found that soil erosion and water pollution, both presented $42 \%$ and $16 \%$ for the impoverishment of soils and the significant positive impacts are directly linked to the generation of employment and income.

5. Miners do not comply with mineral legislation, putting the economic issue ahead of the environmental one and compromising not only the conservation objectives of the protected areas, but also the essential products and services to life from natural ecosystems.

\section{ACKNOWLEDGEMENTS}

The authors express their gratitude to the Ministry for Foreign Affairs in Finland for providing financial support through the Sustainable Management of Natural Resources in Mozambique (SuMNatuRe) project.

\section{REFERENCES}

1. Bitar, O.Y. (1997). Avaliação da Recuperação de Áreas degradadas por Mineração na Região Metropolitana de São Paulo. 185 f. Tese (Doutorado em Engenharia) - Universidade de São Paulo.

2. Case, D. (1990). The Community's Toolbox: The Idea, Methods and Tools for Participatory Assessment, Monitoring, and Evaluation in Community Forestry. Community Forestry Field Manual 2. Rome

3. Centro de Integridade Publica - CIP. (2010). "Questões à volta da Mineração em Moçambique Relatório de Monitoria das Actividades Mineiras em Moma, Moatize, Manica e Sussundenga” Maputo.

4. Deniasse, O.A. A (2019). problemática ambiental da mineração artesanal em Manica-Moçambique: Propostas de Solução. Maputo: Ethale Publishing.

5. Dondeyne, S., Ndunguru, E., Rafael, P., Bannerman, J. (2009) Artisanal mining in central Mozambique: Policy and Environmental issues of concern, Resources Policy 34

6. Ganje,J; Mulima, E; Cristóvão, L (2021). Ethnozoological Impacts on Fauna Conservation: The Case of Chimanimani National Park. The Journal of Resources Development and Management, 76 (16-21).

7. Ghiurghi, A., Dondeyne, S. \& Bannerman, J.H. (2010). Chimanimani National Reserve. Management Plan, Volume 1. Report prepared by AgriConsulting for Ministry of Tourism, Maputo, Mozambique.

8. Geoide Consultoria Limitada (Geoide). (2010). Estudo sobre a "Mineração Artesanal, Associativismo e Tecnologias Para o seu Aproveitamento Sustentável “ Moçambique. 2010.

9. Iniciativa para Terras Comunitárias - ITC. (2010). Estudo sobre a "Mineração Artesanal, Associativismo e Tecnologias Para o seu Aproveitamento Sustentável". Chimoio. 80p.

10. Lakatos, E., \& Marconi, A. (2003). Fundamentos de metodologia científica (5 ed.). São Paulo: Atlas.

11. Schmied, P. (2018). Guia Rápido para Recolha de Dados com Telemóveis. People in Need. IndiKit. 2p.

12. Villegas, C., Weinber, R., Levin, E., Hund, K (2012). Artisanal and small-scale mining in protected areas and critical ecosystems programme. Global solutions study. WWF report. 